\title{
Keep Calm and Carry On: European Consumers and the Development of Persistent Resilience in the Face of Austerity
}

\author{
Authors \\ Isabelle T. Szmigin, University of Birmingham, UK \\ Deirdre M. O'Loughlin, University of Limerick, Ireland \\ Morven G. McEachern, University of Huddersfield, UK \\ Kalipso Karantinou, Athens University of Economics and Business, Greece \\ Belem Barbosa, University of Aveiro, Portugal \\ Grigorio Lamprinakos, Athens University of Economics and Business, Greece \\ Eugenie M. Fernández-Moya, CUNEF, Spain
}

Isabelle Szmigin is a Professor of Marketing at the University of Birmingham and her interests lie primarily in the areas of consumer research, services, ethical and social marketing. She is particularly interested in the intersection between business and social policy and understanding people's experiences of consumption.

Deirdre M. O'Loughlin is a Senior Lecturer in Marketing at the University of Limerick, Ireland. Her research interests include consumer behaviour within a variety of contexts in addition to services, branding and digital marketing. She has published broadly in international journals including the Journal of Service Research, Sociology, Journal of Marketing Management, Social Policy and Administration, Advances in Consumer Research and the Journal of Higher Education Studies. She has presented her research widely at many peer-reviewed European and international conferences.

Morven G. McEachern is Professor of Sustainability at the University of Huddersfield. Her research interests primarily lie in the area of business and consumer ethics and various consumption contexts. In addition to international conferences, her research has appeared in Consumption, Markets and Culture, Sociology, Journal of Marketing Management and the Journal of Business Ethics. She has co-edited various Journal special issues around her research interests; contributed to edited books (e.g. The Ethical Consumer, Sage, 2005) and is co-author of Contemporary Issues in Green and Ethical Marketing (Routledge, 2014).

Kalipso Karantinou ( $\mathrm{PhD}$ ) is Assistant Professor of Marketing at the Athens University of Economics and Business (AUEB). Her research and teaching expertise lies in the areas of services marketing, consumer behaviour, and innovation management. Her published work has appeared in a range of academic journals, including Sociology, Journal of Consumer Behavior, Journal of Marketing Management, Journal of Services Marketing, Journal of Financial Services Marketing, Creativity and Innovation Management, and Journal of General Management. Kalipso has also contributed to the 2005 and 2014 Wiley Encyclopedia of Management and is a member of the executive committee of the European Marketing Academy (EMAC). 
Belem Barbosa received her PhD in Business and Management Studies, specialising in Marketing and Strategy from the University of Porto. She is Adjunct Professor at the University of Aveiro and currently programme director of the MSc in Marketing. She is a member of GOVCOPP, the Research Unit on Governance, Competitiveness and Public Policy. Her research interests lie primarily in the area of consumer behaviour, including word-of-mouth communication, internet marketing and sustainability marketing.

Grigorios Lamprinakos is a Ph.D. Candidate in the department of Marketing at the Athens University of Economics and Business (AUEB). His research interests lie in the areas of consumer psychology, consumer behavior, emotions, attitude change and persuasion. He has published in academic journals, including the European Journal of Social Sciences Education and Research and Advances in Consumer Research. Grigorios has also presented a number of papers in international conferences such as the General meetings of the European Association of Social Psychology and the International Conference on Social Sciences.

Dra. María Eugenia Fernández-Moya is a Senior Lecturer in Marketing at CUNEF, Madrid, Spain. Her research interests lie primarily in the area of consumer behaviour. She is particularly interested in the luxury marketing research and reccesion research. She has presented papers in different institutions and international conferences. 


\section{Keep Calm and Carry On: European Consumers and the Development of Persistent Resilience in the Face of Austerity}

\section{Purpose}

In the context of European consumers' experiences of austerity, this study aims to advance current resilience theory in marketing through developing persistent resilience from a context of austerity influenced consumption.

\section{Design/methodology/approach}

Following an interpretivist approach, thirty-eight face to face, in-depth interviews were conducted with European consumers from Ireland, UK, Spain, Portugal, Italy and Greece who were affected in some way by the global financial crisis.

\section{Findings}

Building upon limited conceptual and empirical investigations in social geography, our analysis identifies the themes of persistent stressors and temporal orientation as constants, alongside day-to-day coping, relating and pragmatism, consumer adjustment, repertoires of resistance and transformation as key elements of persistent resilience within the consumption context of austerity.

\section{Research limitations/implications}

Our study addresses the limited theoretical and empirical focus on persistent resilience and austerity and directly contributes to consumer behaviour and marketing theory in understanding persistent resilience and its implications.

\section{Practical Implications}

Changes to behaviours as a result of persistent resilience included reducing and stopping consumption, discount shopping, alternative consumption in the form of growing or making and mindful consumption through wastage reduction and re-use.

\section{Social Implications}

Our study highlights the significant social impact of austerity while also identifying positive outcomes for social relations among family, friends and the wider community.

\section{Originality/value}

This study develops and extends Golubchikov's (2011) conceptual theory of persistent resilience through analysis of European consumer responses to austerity, identifying key consumption characteristics relevant for marketing theory and practice.

Keywords: Persistent resilience; Austerity; Financial crisis; European consumers; Coping strategies, Consumer transformation.

Paper Type: Research Paper 


\section{Introduction}

The global financial crisis of 2008 is said to have triggered the most significant economic downturn since the Great Depression of the 1930s (Griskevicius and Millet, 2011). Several Euro-linked EU governments including Greece, Spain, Ireland and Portugal, had to accept austerity policies signalling their commitment to reduce deficits and reach annual targets set by the European Commission, International Monetary Fund and European Central Bank. Several scholars have identified the axiological problem surrounding political and ideological discourses on austerity where governments have held austerity as a moral solution to the sins of excessive spending while also calling for continued consumption to maintain growth policies (Peston, 2012; Bramall, 2013; Blyth, 2013). While austerity has received extensive attention as a political and economic force (Blyth, 2013; Krugman, 2012), there has been less focus on its impact on consumers (c.f. Boost and Meier, 2017; Karanika and Hogg, 2016; O'Loughlin et al., 2017a; Cappellini et al., 2014 for some exceptions). Studies have investigated the effect of austerity measures on aggregate consumption (Kamakura and Du, 2013; Porral et al., 2016), marketing budgets and business strategies (Currim et al., 2016; Rollins et al., 2013), but there has been relatively little focus on how consumers have responded to the economic challenges of austerity in terms of their resilience (Cappelini et al., 2014; O’Loughlin et al., 2017b; Koos et al (2017). Previously resilience was portrayed as a one-off response to a major event but with an ultimate return to a previous state (e.g. Norris et al., 2008). Resilience in the face of austerity is, however, less likely to be about bouncing back, rather adapting to ongoing economic challenges that continue over time. This paper advances theory by arguing that the extenuated circumstances of austerity can reveal a form of resilience that is less about bouncing back to normal but rather moving to a new reality.

The framing of austerity reflects the neo-liberal context in which consumers are expected by governments to demonstrate restrained and responsible consumption in addition to "ethical self-understanding" (Giesler and Vereslu, 2014, p. 851). This study explores consumer resilience to austerity during prolonged economic downturn in Europe. The paper identifies streams of resilience theory most relevant to the marketing context including psychological and sociological in addition to consumer coping and the effects on consumption. Our conceptualisation of resilience differs from extant psychological, social, community resilience and coping theories, and presents an approach that has emerged from social geography. Through theoretical and empirical exploration of what is termed persistent 
resilience (Golobchikov, 2011), the paper responds to Koos et al., (2017) who identified the lack of research around temporality, resilience and the durability and persistence of changes to consumption in response to crises.

A key characteristic of persistent resilience is its enduring quality which contributes to it being an appropriate lens through which to explore European consumers' response to the long-term effects of austerity. Responding to the opportunity to advance theory, our study presents persistent resilience within a framework of persistent stressors and a temporal orientation, developing persistent resilience theory in the context of austerity. We begin by examining the literature on consumer coping and consumption, followed by a review of resilience research before presenting the concept of persistent resilience, which is followed by an explanation of the methodology, findings and conclusions with particular emphasis on the consumer and marketing context of persistent resilience.

\section{Consumer Coping and Consumption}

Previous research has explored individual and community coping strategies to various crises and economic downturns (e.g. Shama, 1981, Ang et al., 2000; Kayaz and Gui, 2014). Behavioural and psychological responses (Mick and Fournier, 1998) as well as adaptations to consumption practices and alterations to shopping patterns such as reduction and changes to spending have been identified (Hampson and McGoldrick, 2013; Lamey, 2014). Exploring the Argentinian economic crises of 2001-2002, Zurawicki and Braidot (2005) discovered among the middle class an overall reduction in consumption and substitution of luxury goods, reduced spending on social events and increased socialising at home. During the Turkish economic downturn, Kaytaz and Gui (2014) reported product and price switching while a Pan-European consumer study of the 2008 economic crisis found the "old" poor were better equipped than those newly financially disadvantaged to cope with insecurity and dependency (Dagdeverin et al, 2017). In the US, Hampson et al., (2018, p. 159) explored varying attitudes and behaviours towards money in the post-recession economy and found that the "flourishing frugal" cluster comprising the highest earners tended towards guilt free hedonic consumption while the "financially distressed" favoured frugality but were vulnerable to impulse buying. In response to such crises, marketers have been advised to demonstrate understanding and empathy towards consumers and to develop appropriate segmentation and positioning 
strategies (Strutton and Lewin, 2012). This is evident in the rise of value and basic own label brands alongside the popularity of discount food stores.

Collective coping to crises reveal the importance of psychological resources (e.g. McCubbin et al., 1980; Epp et al., 2014; Bartfield and Collins, 2017) and in particular the "regenerative power" of the family in recovering from disruptive stressors (McCubbin et al., 1980, p. 856). Often families undergo chronic long-term stressors as a result of unemployment (e.g. Zestanakis, 2018) with financial adaptations ranging from relying on savings, borrowing from family and friends, increased work effort and use of mainstream credit (Bartfield and Collins, 2017). Similar to the chronic stressor of long-term unemployment during the recession of 1970s (McCubbin et al., 1980; Moen, 1979), the effects of austerity persist for many consumers in the EU. In this paper, we argue therefore for the need to go beyond the reactive and short-term aspects of consumer coping theories and examine the longer-term aspects of austerity on consumers framed through the concept of persistent resilience.

Persistent resilience is conceptualized as a form of enduring engagement with the continual challenges and pressures of everyday life (Golubchikov 2011). A key feature of persistent resilience is that in response to sustained stressors, individuals engage in incremental and significant life changes over extended time-periods in contrast to short-term coping strategies. The paper examines how persistent resilience is enacted by a sample of European consumers all of whom have experienced austerity over the last 10 years. We firstly consider traditional concepts of resilience as forms of response to problematic or traumatic situations, followed by an examination of how persistent resilience is distinguished from such concepts before investigating its relevance to the current austerity context.

\section{Resilience}

Despite the extensive literature on resilience there is a lack of agreement regarding its meaning and practical implications (Herrman et al., 2011; Raab et al., 2015). The varying definitions emanate from psychology (Lazarus 1993), organizational studies (Weick and Sutcliffe 2007), sociology (Evans and Reid 2013), consumer research (Ball and Lamberton 2015), disaster studies (Baker and Baker 2014; Ozanne and Ozanne 2016), ecology (Adger 2000) and spatial studies (e.g. Andres and Round 2015). Different types of resilience have 
been identified, including psychological (Block and Kremen 1996), behavioural (Robertson and Cooper 2013), community-based (Mason and Baker 2014; Baker 2009) and social resilience (Koos et al., 2017). Psychological resilience has been characterized by the ability to bounce back from negative emotional experiences and by flexible adaptation to the changing demands of stressful experiences (Block and Kremen, 1996; Lazarus, 1993). Returning to a previous state is a common theme in the literature, where resilience is described as "the developable capacity to rebound or bounce back from adversity, conflict, and failure or even positive events, progress, and increased responsibility" (Luthans, 2002, p. 702). Resilience is also associated with both reactive and proactive responses involving recovery, learning and growth (Youssef and Luthans, 2007, p. 778). This suggests that resilience can be developed during a process of adaptation to events which, in turn, may have either a sensitising or strengthening effect (Rutter, 2012).

Personality traits are also considered in the psychological and behavioural context of resilience. Haglund et al., (2007) present attitudinal and behavioural factors including positive attitude, active coping, cognitive flexibility, moral compass, physical exercise, social support and role models. This association with personality and individual differences implies a "generalised, characterological quality of an individual" and does not solely apply to a single or specific behaviour in response to an adverse event (Block and Kremen, 1996, p. 351). More recently, it has been suggested that, while resilience may be related to underlying personality, it is not a fixed characteristic or trait (Cooper et al., 2014) and can be developed and strengthened over time and in response to events.

Within communities, resilience has been explored in terms of the response and ultimate recovery demonstrated by collective groups to one-off disasters such as earthquakes and tornados (Norris et al., 2008; Baker and Baker; 2014; Ozanne and Ozanne, 2016). The focus is on the community's or group's capacity to bounce back from an adverse event through drawing on key information resources such as accessible, local and trusted communication (Longstaff, 2005). There is also increasing acknowledgment of not only how communities face single-event disasters but also how they "organize capacities in the face of on-going disasters" (Ozanne and Ozanne, 2016, p. 5). This may include harnessing technology and social media to facilitate story sharing and catharsis among those affected by disasters (Veer et al., 2016). 
Social resilience looks to how social systems respond, re-organise and renew through change (Folke, 2006), resulting in structural transformation in society (Koos et al., 2017). Here, social resources and outcomes in building resilience can lead to "changes in market demand and transformed activities and solidarities" (Koos et al., 2017, p. 363). In developing social resilience, individuals respond to the broader social context and moderate their behaviours and consumption relative to others in the face of a crisis (Kamakura and $\mathrm{Du}$, 2013). Recent research on social resilience has identified countries' responses to long-term economic crises, with, for example, German consumers engaging in smart consumption and self-production to boost self-esteem (Boost and Meier, 2017), and Brazilian consumers leveraging socio-cultural resources, market-mediated socialisation and material improvement to build a new middle class identity (Castilhos et al., 2017). In the UK, social resilience has in some cases led to positive changes in values and new forms of exchange (Hampson and McGoldrick, 2017; Koos et al., 2017) whereas, in Spain, the comparative severity of the economic crises has significantly tested people's social resilience and, in some cases, negatively affected social mobility, identity and class perceptions (Alonso et. al., 2017).

From a temporal perspective, while many resilience studies suggest an end-point to and an ultimate recovery from, adversity and negative experiences, others recognise that the modern environment has become increasingly unpredictable (Ozanne and Ozanne, 2016; Evans and Reid, 2013). Rather than being a response to extraordinary events, resilience may develop from relatively ordinary, everyday situations (Bonanno, 2004). There is recognition that it can enable people to re-emerge from ongoing adversity, to which they must be increasingly responsive (Neocleous, 2012; Evans and Reid, 2013; Duffield, 2011). The more severe, unexpected and enduring the stress, the stronger individual resources may need to be to create resilience that will enable a flexible and continuous adaptation to the altered environment (Norris et al., 2008). Given the sustained nature of austerity, we suggest that such conditions call for an enduring form of resilience or persistent resilience which we present next.

\section{Persistent Resilience}

Golubchikov (2011, p.4) introduced the term persistent resilience in response to increasing uncertainty brought about by economic, social and climate change, defining it as "a form of engagement with more enduring, lasting challenges and pressures, especially those 
challenges that underlie everyday life, [and] are mundane". He argues that persistent resilience allows for a proactive and continuous renegotiation of everyday life practices and relationships and accommodates "continuities of change and reciprocity". According to Golubchikov (2011), the potential to become increasingly marginalised, excluded and/or displaced from the marketplace is particularly significant for EU consumers if they fail to proactively tackle austerity in the long-term. Persistent resilience is presented as a response to the pressures of modern society but also as a coping strategy over prolonged periods of austerity experienced by many Europeans. It can therefore be viewed from both a social and an individual perspective. More recently, De Verteuil and Golubchilov (2016) highlighted the persistent renegotiation and restructuring of common, everyday practices, drawing on the power of resources and networks to effect incremental change which may form the basis for more significant transformation at both an individual and societal level. They suggest that persistent resilience can be actively produced such that while people may not be able to change their circumstances, they develop agency in coping with austerity. This emphasises persistent resilience as a negotiated phenomenon rather than a normative form of overcoming adversity.

To date, we have only identified one empirical study of persistent resilience (c.f. Andres and Round, 2015). Andres and Round (2015) describe persistent resilience as the micro-level of households and individuals within a defined spatial boundary of a housing estate in the UK. They analyse how "households and their networks develop responses not just to 'shocks', but also to more long-term processes, such as the changing nature of employment and/or responses to constantly altering state policies" (Andres and Round, 2015, p. 676). They describe how households respond to the everyday pressures of low incomes, benefit payments and the persistent resilience required as local manufacturing declines with the resultant impact on employment. Rather than bouncing back to a previous state, their participants pursued a variety of strategies of persistent resilience which resulted in better housing and retail offerings along with supportive community projects and individual persistent coping tactics, such as shared caregiving networks within the housing estate.

In taking up De Verteuil and Golubchikov's (2016, p. 144) challenge that the theory of persistent resilience is flexible enough to work as an analytical tool for "a variety of systems and temporal frames", we apply the theory to a consumer context. In so doing, we build on Golubchikov's (2011) initial conceptualisation. Our approach also corresponds to Andres and 
Round's (2015) micro-level analysis but is beyond the spatial boundary of a specified place/housing estate to a cross-section of European participants. A decade following the global crisis of 2007/2008, austerity remains an enduring force, creating significant and sustained turbulence and insecurity for many EU societies and is an appropriate context in which to investigate persistent resilience.

In Golubchikov's (2011) framing of persistent resilience, the relational element refers to people's web of social relations that enable coping strategies and dynamic refers to the active rather than passive management of one's social relations. Spatial relates to the actuality of "everyday life, real-world coping strategies" (p. 5) enabled through the removal of the prescriptive and the renegotiation of the spaces which people occupy. Political gives people a voice, removes their dependence on top-down coping strategies and views them as actors rather than victims. While this theory from social geography offers marketing opportunities to progress social and temporal theory and practice, it is recognised that the specific aspects of persistent resilience in a consumption context may be somewhat different. So while coping with the actuality of daily life link to the economic constraints that may impact consumption choices, the voice of the consumer is less likely to be heard in an overt way although choices such as shopping at discount stores or reducing waste may be viewed as political activities. It is therefore the theoretical advancement of persistent resilience through its conceptual exploration within the consumption context of austerity that is the key purpose of our paper.

In this paper, the investigation of persistent resilience is advanced within a range of consumption contexts affected by austerity. Rather than focusing on the resilient consumer as a normative response to risk and danger (Evans and Reid, 2013), it conceptualises how persistent resilience is enacted (Arsel and Bean, 2013) by a sample of European consumers. In contrast to the traditional perspective of coping which is predominantly conceptualised as a reactive, economic and psychological response to short-term crises (Hampson and McGoldrick, 2013; Ball and Lamberton, 2015), the paper builds on theories of consumer coping and social resilience, emphasising the dynamic and temporal aspect of persistent resilience. Social and community responses embodied by social resilience may be part of the persistent resilience picture but we emphasise that it incorporates a broader set of enduring responses. Table 1 offers an illustration of this theoretical trajectory, comparing extant theories of coping, resilience and persistent resilience within urban studies with our conceptualisation of persistent resilience extended to a marketing and consumption context. 
Prior to discussing our themes and how we build upon Golubchikov's (2011) limited conceptual exploration of persistent resilience, we describe our adopted methodology.

Insert Table 1 here

\section{Methods}

Following an interpretive turn (Spiggle, 1994), face-to-face, in-depth interviews were chosen as an appropriate form of social enquiry (Denzin and Lincoln, 1994; Miles and Huberman, 1994). The interview process was based on a long interview protocol (McCracken, 1988), which aimed to explore the effects of austerity in terms of changes to everyday behaviour and experiences, comparing how things were done prior to and during austerity. After receiving ethical approval from our respective University Ethics Research Committees, the semi-structured interviews began with some global questions regarding the home, leisure and working lives of participants before moving on to more detailed questions regarding their consumption and day-to-day family and work life.

Participants came from six European countries (Ireland, UK, Spain, Portugal, Italy and Greece) affected to a lesser or greater extent from the global financial crisis. Employing a purposive sampling approach, 38 participants were interviewed across the 6 countries, representing a range of demographics e.g. age, gender, life-stage and income, including unemployed people (See Table 2). The demographic and socio-economic diversity of our participant profiles makes a useful contribution in understanding the lived reality of how individuals of various ages, gender, socio-economic grouping and family size coped with austerity. Participants were recruited in a number of ways across the countries, including through social networks, special announcements and further snowballing. The interviews took place either in the participant's home or a room at the University and ranged in length from 45 minutes to 2 hours.

Insert Table 2 here

Interviews carried out in Spain, Portugal, Italy and Greece were conducted by experienced, bilingual researchers and translated into English. The transcripts were subsequently coded by all members of the research team, to facilitate a form of back- 
translation (see Horváth and Birgelen, 2015) as subsets of transcript codes were discussed and compared across all countries. As there is no one single best way "to generate or evaluate interpretations" of our data (Ahuvia, 2001, p.161), a thematic analysis approach was used to move from description to interpretation (Clarke and Braun, 2013). Although often confused with content analysis, thematic analysis applies minimal description (i.e. supports interpretation of the data) and does not involve any quantification of the data (Gbrich, 2007). While content analysis and thematic analysis share the similar aim of analysing narratives, the thematic analysis approach involves becoming familiar with the data and generating initial codes, conducting a deductive-inductive identification and review of themes, followed by the defining, naming and reporting of themes (Braun and Clarke, 2006; Braun and Clarke, 2012). Thus, the research team performed cycles of coding and theoretical reviews. It was during the theoretical review process that the research on persistent resilience was identified as having resonance with the data. Following this stage of theoretical review, further coding and the refinement and development of themes in comparison with the original theory was completed.

The rationale for the final analysis is developed from Golubchikov's (2011) untested characteristics of persistent resilience, namely relational, dynamic, spatial and political. As presented in the next section, these are both drawn from and built upon in the analysis. The purpose is to build on this existing, but limited in empirical testing, theory to identify whether what is happening among Europeans faced with austerity can be conceptualised through persistent resilience and what implications there are for marketing. In qualitative research, it is important to report on "procedures of inference" (Spiggle, 1994, p.501), hence, as is characteristic of thematic analysis approaches, our thematic map (Braun and Clarke, 2006) visually illustrates the relationship between the codes, themes and our data (see Figure 1).

\section{Insert Figure 1}

In the development of persistent resilience based on the thematic analysis, acknowledgement is made of day-to-day coping as a key element of persistent resilience. It is also argued that the scope of persistent resilience is multifaceted and goes beyond a singular focus on collective responses embodied by community resilience or shared responses represented through social resilience. However, the importance of social inputs and outputs is recognised and represented through the concept of relating alongside pragmatism as 
important aspects of persistent resilience. Further, we present repertoires of resistance adapted from social resilience (Koos et al., (2017, p.), consumer adjustment and transformation as features identified in the thematic analysis. This empirical development of persistent resilience for a consumption context identifies dynamic responses that emerge from periods of persistent stress and offers marketing theory a deeper and wider conceptualisation of resilience under austerity. The accompanying narrative regarding our conceptualisation of persistent resilience is presented next in our findings and discussion section.

\section{Findings and Discussion}

Building on the resilience literature, the conceptual work of Golubchikov (2011) and the empirical study of Andres and Round (2015), the paper presents a theoretical proposition for the concept of persistent resilience within the consumer context of austerity. Our conceptualisation incorporates and develops existing theories in areas including social resilience and coping but responds to the particular situation of austerity. The rationale for this theory development comes from Oswick et al., (2011) who call for more theoretical blending through analogical reasoning rather than one way borrowing. Therefore, while we began to identify similar themes to those of Golubchikov (2011), we recognised that these themes could be further developed and built for a consumer context. To help appreciate and understand the contextual nuances regarding our themes (see Figure 1), we firstly acknowledge and discuss the influencing role of two themes which we identify as constants, (i.e. an occurrence which takes place and may re-occur over time) namely persistent stressors (McCubbin et al., 1980) and temporal orientation.

\section{Persistent Stressors}

As noted by Boss (1988), persistent stressors are not necessarily negative but, in the case of persistent resilience, it is likely that they mostly are and include economic, social and cultural pressures. Persistent stressors naturally arise from the context of austerity unlike an earthquake or similar physical trauma which may have after-effects that continue for a long time, austerity has exhibited its drip-like effects for years. Many causes could be characterised as persistent stressors, such as racism, bullying or even a chronic disease and 
the critical factor in our conceptualisation of persistent resilience is that there is a prolonged time period of the same or similar pressure being exerted upon people.

Examples of persistent stress are displayed by Maria (49, Stay at home Mum) who described the Portuguese as experts in economic crises because most had lived through two. She saw an upside to this, "they're useful [i.e. periods of economic instability]. It's a good school of life, we know how to live with a little". In response to her own compulsory redundancy, Lisa (40, UK, Self-Employed Transcriber) set up her own home-based business to then experience a month later, three separate redundancies made to her partner over a two year period. Similarly, the ongoing nature of persistent stress is present for Gino (47, Italian, Self-employed) who described how employment contracts had not been updated for years and "as a consequence wages are stagnant while prices are constantly rising”. Stress for Amelia (21, Portuguese, Unemployed Shop Assistant) had originated with her parents living with debt, but when her father lost his job, even basic things became a problem. Now unemployed, she complained about jobs where payment wasn't forthcoming: "in my case it's the second time and in my boyfriend's case it's the third because we don't receive the money we work for; we can't make plans and that's why we're afraid of disillusionment'. As a consequence, she has indefinitely postponed her wedding.

While persistent stressors in this study are primarily economic, they can affect relations with family and friends and people's identity within their social and relational networks. The impact of losing a job makes life more precarious and opportunities for improvement are economically constrained which in turn adds to worries about one's children's wellbeing and relations with family and friends.

\section{Temporal Orientation}

The second constant illustrates a temporal orientation. In identifying the notion of temporality as a constant influence on consumer behaviour, we see people's lives as affected by their past, present and future within the context of austerity. We unveil different approaches which exemplify persistent resilience including not planning for the future but living in the present. Building upon Weinberger et al., (2017, p347), some participants had a clear "imagined future" while others lived with an apparent absence of choice that meant life was lived on a day-by-day basis. Conversely, others save, consume differently and some make extreme plans to safeguard their future. While we did not note a class distinction across 
participants in regard to their temporal orientation, for those who had more precarious occupations or were unemployed, the fear of the present, let alone the future, led to a yearning for stability, as expressed by Elisa (46, Greek, Part-time Teacher): “To plan you need stability, some stable variables. There is nothing stable here. There is no planning now. How can you plan with all these unexpected developments"? An imagined future however could be difficult even for those working in professional occupations: "Now thinking about the future, I don't think a lot... instead I try to prevent things... I work to maintain some saving for them" [her children] (Helena, 39, Portuguese, Architect).

Many people spoke of the lives of their children and grandchildren, what they might look like and what they could do for them: "I don't feel there are big changes to my way of life, just the worry about the future of my children" (Ana, 58, Spanish, Unemployed) and some younger participants even felt that they would not be able to afford to have children. While some had general fears, others were quite specific in their concerns for their children:

"I don't know if I'm going to be able to what I was planning on doing. My daughter says that she wants to be a doctor and I don't know if I'm going to be able to pay her university; I'm scared of not being able to do so" (Manuel, 53, Portuguese, Unemployed). In a case such as this it could be argued that however resilient the person may be, the reality of their economic position will stop them from finding a way through.

Some participants' imagined futures engaged with different strategic actions including the possibility of emigrating: "I' $m$ thinking of leaving the country if I don't find the proper job in the next 2 months - maybe Canada" (Luismi, 27, Spain, Unemployed/Part-time Student).

A few participants reflected on how their current situation compared to the past. Here Alma (54, Irish, Part-time Volunteer) presents her husband's view of the past "No, it was worse, we went through worse...we didn't have a car until Aoife was born. ... We didn't have a landline phone. We didn't have things we couldn't afford", while Linda's plans to travel with her husband after he retired were put on hold: "I'd love to do it now, but there's just no way. No chance" (Linda, 55, UK, Carer). Focusing on a temporal orientation reveals some were able to "count their blessings" while others strived for stability, or feared the future. For a minority of participants a more radical strategic action was called for which could mean 
leaving their country or seeing as in the case of Filipe (65, Portuguese, Doctor), both his children working abroad.

Alongside the two constants presented above, there are elements that characterise persistent resilience including day-to-day coping, relating and pragmatism, repertoires of resistance, consumer adjustment and, for some, transformation. Our analysis identifies that the latter three aspects impact in particular on consumption activities. We do not however suggest that persistent resilience is universally found among participants and, as will be seen, there is deep uncertainty and even fear of what lies ahead, particularly for future generations.

\section{Day-to-day Coping}

In Golubchikov’s (2011) framing of persistent resilience, as discussed, "dynamic" refers to the active rather than passive management of one's social relations and "spatial" relates to the actuality of "everyday life, real-world coping strategies" (p.5). In this study, these two elements have been conflated into a single theme of day-to-day coping, as, while to some, coping may sound like a passive response, our data demonstrates people taking active decisions to enable coping strategies. Working out how to cope is essential to maintaining resilience over time. As people found different ways to manage reduced circumstances, they gained a sense of achievement. Sometimes this was purely practical, such as cutting down on non-essentials or learning to mend things that previously they would have outsourced. For example, Mirella (51, Italy, Sales Representative) stated: "We always try to fix things ourselves" and Robert (38, Ireland, Senior Court Clerk) acknowledged that "You become an expert quickly, when you tackle it yourself'". For Rita every aspect of cutting down on consumption was investigated:

We go out less, I do not go out as much and I try to stay home with my husband on the weekends: the get-togethers happen less. With food expenses, I try to do cheaper shopping, have a shopping list, so that I know exactly what I have to buy... With electricity, I try to turn everything off. I save this way, do less washes, I try to accumulate more and try to wash everything in one load; I also save water, I do not leave the tap running (Rita, 33, Portugal, Petrol Station Shop Assistant). 
While the experience of austerity was generally difficult and, for some, traumatic, coping with it led to some creative responses:

...it's like going through a dark tunnel and you're saying "when will this end" and "when will this ease"? So rather than be thinking about that, why shouldn't I do something about it?... and that is where this [a charity started by Simone] came from! (Simone, 46, Ireland, Founder of Charity).

Day-to-day coping as a process of engagement with difficult situations was evident in a number of participants who were determined to help others as in the case of Simone's charity. Similarly, Elisa framed her coping strategies and initiatives in relation to her values and motivation to help others:

I feel really bad amidst the crisis, but on the other hand, it gives me strength to do three things. One is to continue being active and dynamic and to try to do the best I can. The second is to try to strengthen these emerging values in my behaviour, in my family and in the people around me, and third, to try to help as much as I can as many people as I can (Elisa, 46, Greece, Part-time Teacher).

While many participants have problems themselves, they recognise coping is not a shortterm state and that it can be difficult to manage on your own. That day-to-day coping becomes a deeper, sustained and even creative factor in people's lives is, this paper suggests, an essential part of a resilience that is maintained over the long-term.

\section{Relating}

Following Golubchikov (2011), relating is a reflection of persistent resilience's web of social relations which enable people to have agency and cope independently of top-down strategies. Social resilience looks to how social systems evolve in response to crises and considers the broader social context in which individuals develop and moderate their behaviour and consumption during a crisis situation (Kamakura and Du, 2013; Koos et al., 2017). Similar to other studies that have identified different social/cultural styles of consumption emerging from social resilience (Boost and Meier, 2017; Castilhos et al., 2017; Alonso et al., 2017), our theme of relating is additionally perceived to relate to the inner 
circle (family, friends, and neighbours) rather than the broader societal orientation in terms of looking at people's social networks.

Our participants' network relations included various forms of giving to and receiving from their close and extended family, friends and the wider community. For example, Manuel (53, Portugal, Unemployed Construction Worker), and father of two, drew on the support and "comfort" of family to help him through a difficult time of financial insecurity: "For me, my family is what is really important, family and people...If I have a problem, she [his wife] has a problem too and we talk things through to get over them... That helped me release some pressure". Manuel goes on to explain how in the past he would have tried to manage on his own but that he has learned to share his financial worries with his wife to reduce the stress he feels. Families worked together to improve their situation, often in small, incremental ways which included financial gifts, part-time work and thriftiness. Luisa's family included three generations all contributing in various ways:

My mother helps me out with all these (everyday expenses for herself and her son) and my sister too. Sometimes my son works part-time, so he earns something even though it is not much. Still he is trying to help as much as he can. (Luisa, 47, Italy, Unemployed Freelance Worker).

The importance of relating was evident at a personal level as shown above while others contributed outside of their friends and family, having a "need to help other people who are in a difficult situation" (Rosa, 60, Spain, Gardner). While such solidarity in the face of austerity among people was evident at a localized level, it could also be recognised at community and national levels with comments such as: "I'm very proud of Spanish people...we are in a terrible crisis, but, still, we have a sense of humor...to be sociable, to go out, to see the positive in our lives" (Elena, 30, Spain, Unemployed University Lecturer). Elena's reflection on the ability of Spanish people to "smile even if the situation is very bad" is testimony to her perception that her compatriots embody collective positivity in response to the severe impact of austerity in their country. 


\section{Pragmatism}

Emerging as an important finding of our analysis of persistent resilience, we identify pragmatism as different to day-to-day coping in that it is not about dealing with the immediacy of the situation people find themselves in but rather it is concerned with their outlook on life that may come from the changed environment and the measures they have taken. In acknowledging the influencing presence of our constants discussed above, pragmatism has a temporal orientation as people think about how they will move forward in their changed worlds; this is central to a concept that deals with the narrative between past and future lives. Differences in time orientation may shape decision outcomes for the near and the distal future, where according to Kogut et al., (2017) high-level idealistic concerns and values often dominate decisions for the distant future, whereas low-level pragmatic concerns play a greater role in decisions for the near future. Building on the differences in orientation towards near and distal futures, we propose that our participants adopt a pragmatic temporality in the ways they reflect on the past and present which in turn shape their perspective of future outcomes.

This pragmatic temporality is illustrated by Elisa (46, Greece, Part-time Teacher) explained how "the situation pushed me into an inner investigation...that is why I consider myself lucky because, of course not every day, but overall, I feel good with myself. I can handle all this and adjust to the new reality". Her recognition and acceptance of the changes in her life led her to embark on a personal critical analysis and she emerged from this believing that overall she could manage her situation and make the necessary adjustments. Yiannis (38, Greece, University Academic) said that he took time to read about the roots of the crisis and from this reflected that "there is an opportunity for a change, but we need to understand what brought us here to be able to bring change. I am trying to understand what has happened, what the reasons were for this and looking into it in a more activist perspective but activist with regards to the fundamentals".

Similarly, Yiannis was not suggesting going on the streets to protest but rather wanted to understand, learn and be part of the voices that could make future changes as "if we leave such decisions to the same few people, nothing will change". He reflected on his own situation too: "уои have to focus on what is realistic. In our job we dream, we aspire to do more important things but you get to realise that these aspirations in the current 
circumstances of the recession are not realistic". While this may seem somewhat fatalistic, it is coupled with an energy to do more: "I try to be more pragmatic, I also try to be a doer, in the sense of being a person who makes things happen". While the data used to illustrate Pragmatism is largely from Greek participants reflecting the particularly severe, longer-term impact of austerity in Greece, this approach to austerity from other countries was not uncommon, reflected by Martina (UK, 44, Librarian) who states "I just really am quite focused on making sure my own; my family's financial management is as good as it can be. I can't do anything about forces outside that. I just think that would be wasted energy". For many, pragmatism reflects coming to terms with a situation over a prolonged period of time whereby people have had an opportunity to consider what they can and cannot control and identify ways to deal with their problems.

In reflecting the process of persistent resilience, we argue that day-to-day coping, relating and pragmatism are key aspects of persistent resilience in response to the constants of temporal orientation and persistent stressor of austerity leading in turn to a range of outcomes including consumer adjustment, repertoires of resistance - negotiating the marketplace and, for some, transformation, which acknowledge the consumption impact of persistent resilience.

\section{Consumer Adjustment}

To help cope with austerity, consumers make adjustments to their own needs and wants and in how they engage with the market place. Adjustment arises from being able to make some self-analysis alongside reacting to the difficult environment. Key adjustments included stopping or reducing certain consumption choices, downgrading consumption through shopping at discount stores or during sale time, looking for alternative ways to consume through growing or making rather than purchasing and more mindful consumption such as reducing wastage and re-use.

Examples of this include, Iron (18, Italy, student), who took one or two day breaks rather than longer holidays and waited for "the sales in order to buy everything then, unless I absolutely need to buy something specific... As a general rule, I buy something only if I really need it". Similar to many others who had to give up things they enjoyed doing; Emma (22, 
UK, Unemployed Office Administrator) regretted that she could no longer continue ballroom dancing or other pastimes as she hadn't a job: "I can't afford it. I love going swimming, but I can't afford to go swimming. I can't afford to do hobbies".

Food was a more controversial issue in terms of changing or downgrading consumption with comments such as "I have that saying in the back of my head "buy cheap, buy twice"" (Ruth, 42, Irish, Community College Teacher) and others prioritising quality in some areas such as meat or fish but relying on discount stores for other items such as Brid (56, Irish, Training Consultant):

In relation to shopping, I was a Superquinn girl... I was Marks \& Spencer...I'd just get a trolley and fill it up... I wouldn't even look... it didn't matter ... And now? I do Aldi first, then I hit Lidl and then I do Tesco. And I go to Superquinn only for fish.

Participants also described how they were being more mindful in their consumption and behaviour more generally, thinking whether they really needed something new, turning lights off and reducing wastage:

We change supermarkets, we change shops, we change everything... we are looking for ways to be careful... Let me give you an example on how consumers behaviour has changed; before the crisis a bottle of body wash was usually disposed long before it was completely empty, but now it is being used up to the last drop. Some years ago you would find 20 different soaps and 10 different shampoos in a 4-member family bathroom. Now they have to share the same bottle of shampoo to economize. Customers are thrifty now and quality matters to them a lot (Giancarlo 47, Italy, Sales Manager).

It is not the habits as such, it is a reassessment of lifestyle that is taking place. We consciously try to be more alert to irrational spending in all our activities (Nikolaos, 41, Greek, setting up new business).

Nikolaos asserted that his actions were not just due to a change in circumstances but a reassessment of what was important in his life. This and the cases above reflect not only changes to behaviour but also deeper adjustments to the meaning of consumption evidenced through a new-found focus on value, quality, thrift, waste reduction, sustainability and 
mindfulness. Whether or not such mindful approaches to consuming reflected in certain cases a change of mind-set, it seems likely that they were for some an outcome of necessity. Not only are adjustments such as these a result of austerity but they also reveal an active agency and responsibilisation (Giesler and Veresiu, 2014) that involved developing and orchestrating skills and resources while exploiting opportunities.

Repertoires of Resistance - negotiating the marketplace

While adaptation required giving up or downgrading in some areas of consumption, alternative ways of doing things presented themselves or were created by our participants. Repertoires of resistance are not necessarily an expression of resistance to the marketplace but rather resistance to austerity that leads to actively finding alternative ways to consume or avoid expenditure. For example, while Luisme could no longer afford the gym, that didn't stop him from working out as he talked about how, "I used to spend over $€ 300$ per year, I bought weights to do some exercise at home".

Helena, a 39 year old architect from Portugal described how 15 women at her office designed a system for sharing baby clothes when one of them became pregnant: " $a$ year and a half ago we-planned that the next baby will take that kit with some clothes that came from the last baby". Yiannis, a 38 years old Greek university lecturer, revived a tradition of joining with friends in each other's houses and eating homemade pizza instead of going out: 'But even in villages during the past 20-25 years that was something that was about to become almost extinct. It has now revived, people getting together at each other's homes".

Some expenditures could also be communal such as for Ruth (42, Ireland, Community College Teacher) who described how she shared house maintenance costs with other neighbours:

My neighbour built the fence out the front so I agreed to share the cost. Yeah and we shared the cost of the fence at the back and now I'm doing...paying for the covering of the roof. So we kind of work together that way.

Meanwhile Maria and her friends engaged in a friendly form of barter, sharing and exchanging home-grown and homemade produce: "someone knocks on my door to share with 
me things that they planted in their garden...So they have already brought me cabbages, lettuce, green beans and zucchinis...it's really spectacular" (Maria, 49, Portugal, Stay at Home Mum). In return Maria gives away lemons.

Golubchikov (2011) argues that in the context of hegemony and uneven power relations, the relational does not idealise people's capacity for change, rather it places people in a broader social context and enables persistent resilience. In our consumption context and through social relations, resistance to the persistent stressors can be enacted in a marketplace. Such resistance reveals a certain proficiency in their ability to connect to others, to weather difficult situations and generate positive outcomes, often outside the usual commercial market-place transactions.

\section{Transformation (or not)}

Both De Verteuil and Golubchikov's (2016) and Andres and Round's (2015) propose that resilience can lead to transformative change. We acknowledge this and extend this theme to include significant changes in how and what people consume. Certainly, our participants noted changes that they believed would be long-term in areas such as more thoughtful consumption, reducing waste, saving more or teaching their children to be careful consumers. Irene (40, Greek, Working in HR) outlines examples of the level of transformation evident among family and friends:

I have seen many changes in people around me, for one my mother and my brother. They now buy nothing. My brother has not been on vacation for three years. Maybe he has not bought any new clothes in this period. For my mother it is the same. They just do not buy things. Then there are people around me who do not switch on the heating at home or they start bringing food from home at work to avoid this cost, or they sell their cars.

Similarly, Giancarlo (47, Italy, Sales Manager) offers another case study of such transformation. As a father of two, the psychological and economic effects of the financial crisis contributed to the breakdown of his marriage. From the depths of despair he talked about rebuilding his life "in a different way": 
When you are facing everything alone, your world falls apart...I had to rebuild my working life, to deal with experiences and to become more dynamic...I would never again earn the same money... We reduced our expenses... at the same time we gave our children a happier life growing up in the company of their grandparents instead of that of a non-family member. These things allowed us to make something out of our lives and pass it on to our children...

Even something as apparently small as shifting from paid child care to grandparents caring for children appears to have been part of Giancarlo's transformation into "re-educating [himself] to live in another way".

Alongside changes in behaviour, transformation was often reflected in changes to values:

With the economic turndown we learn how to save and how to compare... We learn because if everything goes back to normal tomorrow and I start to earn a good salary again, I will do exactly what I'm doing now because your way of thinking has to change. Later in life we don't know if we're going to come across difficult times again and we shouldn't only act this way when that time comes (Manuel, 53, Portugal, Unemployed Construction Worker).

Before I was surrounded by things and now I realize I do not need anything. You start to appreciate other things (Antonio, Spain, 38, Unemployed Commercial Director).

Both Manuel and Antonio made clear in their discussion that their lives had changed because of economic pressures and that this had resulted in a transformation in their values and attitudes towards what they needed and what they wanted to consume alongside the reality of what they could afford to consume. It is possible that the transformations described here will lead to a long-term realignment of values coupled with a fundamentally different approach to living and consuming and, as a result, there may be significant implications for how such people respond to marketing. This change in what was valued and how people approached the marketplace ran through the narratives of many participants. Although this question was not specifically asked, there was not one person who said they wanted to go back to their previous lives. 
While such transformation was recognised among some participants, clearly it cannot be an inevitable outcome for everyone with some struggling to develop resilience to enable them to transform while others remained largely unaffected. Many people were sad, worried, and anxious as reflected by Mia who felt, "stressed, angry, sad, exhausted and tired" (Mia, 51, Italy, sales representative), while Christina talked about feeling "really stressed and pressurized' (Christina, 53, Greece, part-time employed artist). Conversely, Nikolas (41, Greece) remarked that his spending patterns had not been affected while Roberta continued with her regular trips to the manicurist and hairdresser saying that she was aware of the pressure others were under but "fortunately I have not experienced it personally yet" (Roberta, 42, Italy, high school teacher and gym instructor). Such differences and inconsistences in participant experiences of the everyday impact of austerity are important to highlight as they directly determine the need for developing resilience capabilities and the requirement to transform.

\section{Conclusions}

Oswick et al., (2011) argued against the simple appropriation of theories from other disciplines and recommended a blending process and analogical correspondence over one way domestication. Theoretically resilience has benefited from considerable conceptual development although little blending has taken place across economics, psychology, organisational, disaster studies and sociology. This study has engaged with the concept of resilience, blended it with appropriate theories primarily in the area of social resilience and developed it through an empirical study to underline the temporality surrounding persistent resilience and consumption responses to austerity.

The paper has applied persistent resilience, to a European consumer context revealing its role in developing marketing theory and understanding consumer behaviour, through describing responses to the pressures of austerity and the coping strategies used. The themes identified have referenced and developed the concept of persistent resilience from Golubchikov's (2011) original theorisation. From this a framework is presented which emphasises the temporal perspective and the future orientation of the theory. An overriding element of this development is the idea of the persistent stressor which in this case is the environment of austerity since 2008. As sustained periods of economic uncertainty and social instability continue, marketing academics need alternative frameworks through which 
to examine and understand consumer responses. Many of these responses include close social relations and supportive engagement with their family, friends and communities which not only enable coping, but also adjustment, resistance and for some, transformation. We identified a concomitant change in consumption approaches that are more far-reaching than just moving to discount stores or sale items and include a focus on reduction of waste, social consumption and a more mindful approach to purchasing and consuming.

Our conceptualisation of persistent resilience is in opposition to previous conceptualisations of resilience as bouncing back from adversity (Luthans et al., 2002). As our empirical exploration of persistent resilience describes, if anything, it is the antitheses of bouncing back, as people have to work through, over time, their responses to austerity and this is rarely a one-off event. How, for example, can we expect people to bounce back from being made redundant three times? While bouncing back may be a suitable way of identifying resilient responses to one-off calamitous events, such as earthquakes or storms (e.g. Baker and Baker, 2014), the longevity and range of deprivations that recent austerity conditions have imposed on some require a different conceptual base from which to analyse people's approaches, attitudes and behaviours. This may mean that changes in consumption will have an equally long-term impact and that once people accept a different way to consume, it may continue, even when the economic situation improves. The degree to which a long-term realignment or misalignment of behaviours and values occurs may be explored in future research using practice theory (Warde, 2005) and represents a potentially interesting extension of this research.

Other contexts such as bullying, sexual harassment, chronic illness or racism could represent similar long-term stressors requiring persistent resilience to overcome or at least live through, and these may be useful foci in which to continue and develop the research. Specifically, it may be interesting to explore the differences in the way persistent resilience is developed in cases when one experiences life-long stressors such as racism and poverty as compared with events that precipitate unexpected change behaviours and meanings of people's lives. Maintaining resilience across time requires flexibility and adaptation. This approach is supported by the recent acknowledgement that communities have to collectively develop capacities and prepare for on-going problems (Ozanne and Ozanne, 2016). From a marketing and consumption perspective, there is a need to acknowledge the impact of such on-going situations, not only in relation to short-term responses in the marketplace, but in 
more permanent changes to values, attitudes and behaviour. These should be seen as an opportunity rather than a threat. People's desire to socialise at home, to grow their own vegetables, to be more sustainable and to teach their children these approaches to consumption offers both existing producers and potentially new niche businesses openings to help enable these preferences.

For marketing practice, there are a number of important lessons from our study that develop on the work of previous scholars who have considered the impact of economic pressures on consumers (e.g. Boost and Meier, 2017; Dagdeverin et al., 2017; Kayaz and Gui, 2014). Marketing strategies that appeal to consumers' core focus on thrift, value and sustainability within the context of a leaner sharing economy are crucial. In consumers' quest for value, alongside short-term responses such as buying cheaper goods, collecting money-off vouchers and shifting store allegiances, they may well change their values around not only everyday consumption but consumer culture more fundamentally. While it is unlikely that any of the participants wish to escape the market, they do want to use it better to suit their circumstances. The data shows evidence of a range of changes in behaviour and of interacting with the market. These include greater self-sufficiency, more ecological awareness, sharing and exchange initiatives, trading down or learning how to maintain products for longer, developing carpentry and market gardening skills and identifying alternative sources of entertainment and experience which might previously have been provided within a commercial context. Marketers must continuously innovate with relevant and appropriately incentivised offerings to entice this new breed of conscious, self-sufficient and asset light consumer to spend. These marketplace developments resonate with the original theorisation from social geography that persistent resilience is actively produced such that people develop agency within economic and social circumstances that they are unable to change (DeVerteuil and Golubchikov, 2016). The data in this study re-emphasises that persistent resilience is a negotiating phenomenon rather than a normative form of overcoming adversity.

The research is not claiming generality of responses for people living through austerity. A limitation of this research may be that it cannot represent the range of circumstances within and across the countries studied nor all the potential inconsistencies and contradictions in the dataset, although some important differences in experiences and responses were highlighted. It is also recognised that through translation some of the nuances of understanding may have been lost. Just recognising the increase in poverty and other negative circumstances 
throughout Europe (Stuckler et al., 2017) tells us that persistent resilience would be impossible for all. If you are old, chronically ill and do not have social or local support mechanisms, developing resilience is difficult. In this research, people were identified who continued to suffer and had not been able to develop resilient capabilities to transform or accept the hardships facing them. While our study acknowledges these negative cases, there is an opportunity to focus future research using longitudinal approaches to explore over time the experiences of those who do not develop persistent resilience and fail to adjust or transform. Nevertheless, most of the participants demonstrated various forms of persistent resilience and had identified some positive aspects of their changed lives. These people remain consumers and are still connected to conventional marketplaces but their changed lives affect their approach to consumption. In particular, waste and extravagance are limited and this often leads to positive alternatives that involve sharing, different forms of exchange and social gatherings. Future research could also examine in more detail how changes in values and attitudes through austerity creatively impact the marketplace, beyond the usual phenomena of discounting and switching to cheaper retailers. Also what, if any, are the impacts of consumers becoming more aware of their consumption and how might this affect the consumers of the future?

This study of persistent resilience therefore does not, like previous resilience research, suggest an end-point or recovery or a focus on the type of personality that is likely to be most resilient. Rather it further advances recent work that has recognized the nature of the current economic environment and its impact on people (Evans and Reid, 2013) and everyday lives (Bonanno, 2004). Building upon its limited conceptual exploration within social geography (Golubchikov, 2011; Andreas and Round, 2015), the present study deepens theoretical and empirical understanding of persistent resilience through analysis within the consumption context of austerity and develops the theory through bringing to the fore the elements of persistent stressors and temporal orientation as essential characteristics of persistent resilience. While many of the participants illustrate the formation of "resilient subjects" with "adaptive tendencies" (Evans and Reid, 2013, p. 85), the contribution of this research is the development of resilience through understanding persistent resilience as a process that happens over time and which results in a range of small-scale and transformative attitudes, behaviours and self-analyses allowing people to continue to engage and positively develop their lives in the face of austerity. It therefore behoves consumer and marketing researchers to acknowledge and examine manifestations of persistent resilience, some of which involve 
radical changes, while others may be the result of developing existing preferences. Such a timely investigation will facilitate an understanding of how markets may adapt and change appropriately while also offering opportunities for new enterprises to develop and flourish and for people to continue to participate positively and resiliently with the marketplace. 


\section{References}

Adger, N. (2000), "Social and ecological resilience: Are they related", Progress in Human Geography, Vol. 24 No.3, pp. 347-64.

Ahuvia, A. (2001), "Traditional, interpretive, and reception based content analyses: Improving the ability of content analysis to address issues of pragmatic and theoretical concern", Social Indicators Research, Vol. 54 No. 2, pp. 139-172.

Alonso LE, Rodriguez, C.J.F., Rojo R.I. (2017), "I think the middle class is disappearing": Crisis perceptions and consumption patterns in Spain" International Journal of Consumer Studies, Vol. 41 No. 4, pp. 389-396.

Andres, L. and Round, J. (2015), “The role of 'persistent resilience' within everyday life and polity: Households coping with marginality within the "Big Society", Environment and Planning A, Vol. 47 No. 3, pp. 676 - 90.

Ang, S.H., Leong, S.M. and Kotler, P. (2000), "The Asian apocalypse: Crisis marketing", Long Range Planning, Vol 33 No.1 February, pp. 97-119.

Arsel, Z., \& Bean, J. (2013), "Taste regimes and market-mediated practice", Journal of Consumer Research, Vol. 39 No. 5, pp. 899-917.

Baker, S. (2009), "Vulnerability and resilience in natural disasters: A marketing and public policy perspective", Journal of Public Policy and Marketing, Vol. 28 No.1, pp.114-23.

Baker, S. and Baker, C.N. (2014), "Narratives of cultural trauma (and resilience): Collective negotiation of material wellbeing in disaster recovery", in NA - Advances in Consumer Research, 42, eds. June Cotte and Stacy Wood, Duluth, MN: Association for Consumer Research, pp. 7-8.

Ball, J. and Lamberton, C. (2015), "Rising every time they fall: The importance and determinants of consumer resilience", in NA-Advances in Consumer Research, 43, eds. Kristin Diehl and Carolyn Yoon, Duluth, MN :Association for Consumer Research, pp. 19293.

Bartfield, J. and Collins, J.M. (2017), "Coping strategies among households with elementary school children in wisconsin”, Journal of Consumer Affairs, Vol. 51 No. 3, pp. 519-548

Block, J. and Kremen, A.M. (1996), "IQ and ego-resiliency: Conceptual and empirical connections and separateness", Journal of Personality and Social Psychology, Vol. 70 No. 2, pp. 349-61.

Blyth, M. (2013), Austerity: The History of a Dangerous Idea, Oxford University Press, New York.

Bonanno, G. (2004), "Loss, trauma, and human resilience: Have we underestimated the human capacity to thrive after extremely aversive events?", American Psychologist Vol. 59 No. 1, pp. 20-8. 
Boost, M. and Meier, L. (2017), "Resilient practices of consumption in times of crisis Biographical interviews with members of vulnerable households in Germany", International Journal of Consumer Studies, Vol. 41 No.4, pp. 371-378

Bramall, R. (2013), The cultural politics of austerity, past and present in austere times, Palgrave Macmillan, London.

Braun, V. and Clarke, V. (2006), "Using thematic analysis in psychology", Qualitative Research Psychology, Vol.3 No. 2, pp. 77-101.

Braun, V. and Clarke, V. (2012), "Thematic Analysis", in Cooper, H. (Ed.), APA Handbook of Research Methods in Psychology, Vol.2., American Psychological Association, Washington, pp. 57-71.

Castilhos R.B., Fonseca M.J., Bavaresco, V. (2017), "Consumption, crisis, and coping strategies of lower class families in Brazil: A sociological account", International Journal of Consumer Studies, Vol. 41 No.4, pp. 379-388.

Cappellini, B., Marilli, A. and Parsons, P. (2014), "The hidden work of coping: Gender and the micro-politics of household consumption in times of austerity", Journal of Marketing Management, Vol. 30 No. 15-16, pp. 1597-624.

Clarke, V. and Braun, V. (2013), "Teaching thematic analysis: Overcoming challenges and developing strategies for effective learning", The Psychologist, Vol. 26 No. 2, pp. 120-23.

Cooper, C., Flint-Taylor, J., Pearn, M. (2013), Building Resilience for Success: A Resource for Managers and Organizations, Palgrave Macmillan, London.

Currim, I., Jooseop L.S. and Zhang, Y. (2016), "Commitment to marketing spending through recessions: Better or worse stock market returns?", European Journal of Marketing, Vol. 50 No. 12, pp.2134-2161.

Dagdeviren, H., Donoghue, M. and Meier, M. (2017), "The narratives of hardship: the new and the old poor in the aftermath of the 2008 crisis in Europe", The Sociological Review, Vol. 65 No 2, pp. 369- 385.

Denzin, N. K. and Lincoln, Y.S. (1994), Handbook of Qualitative Research, Sage, Thousand Oaks.

DeVerteuil, G. and Golubchikov, O. (2016), “Can resilience be redeemed?", City, Vol. 20 No. 1, pp. 143-51.

Duffield, M. (2011), “Total war as environmental terror," South Atlantic Quarterly, Vol. 110 No. 3, pp.757-69. 
Evans, B. and Reid, J. (2013), "Dangerously exposed: The life and death of the resilient subject", Resilience, International Policies, Practices and Discourses, Vol. 1 No. 2, pp. 8398.

Epp, A. M., Schau, H. J., \& Price, L. L. (2014), "The role of brands and mediating technologies in assembling long-distance family practices", Journal of Marketing, Vol. 78 No. 3, pp. 81-101.

Folke, C. (2006), "Resilience: The emergence of a perspective for social-ecological systems analyses", Global Environmental Change, Vol. 16 No. 3, 253-267.

Gbrich, C. (2007), Qualitative Data Analysis: An Introduction, Sage Publications, London.

Giesler, M., \& Veresiu, E. (2014), "Creating the responsible consumer: Moralistic governance regimes and consumer subjectivity", Journal of Consumer Research, Vol. 41 No. 3 , pp. 840-857.

Golubchikov, O. (2011) "Persistent resilience: Coping with the mundane pressures of social or spatial exclusion: Introduction to a special session." Proceedings from $R G S-I B G$ Annual International Conference, 2 September 2011. London, pp. 1-5.

Griskevicius V. and Millet K. (2011), "Strategic spending in booms and busts: Surprising effects of economic recessions on consumer behaviour, Advances in Consumer Research Vol. 39, pp. 7-11.

Haglund, M.E., P.S. Nestadt, N.S. Cooper, S.M. Southwick, and D.S. Charney. (2007), "Psychobiological mechanisms of resilience: Relevance to prevention and treatment of stressrelated psychopathology". Development and Psychopathology Vol. 19 No. 3, pp. 889-920.

Hampson, D. P., \& McGoldrick, P. J. (2013). "A typology of adaptive shopping patterns in recession”. Journal of Business Research, Vol. 66 No. 7, pp. 831-838.

Hampson D.P, McGoldrick PJ. (2017), "Antecedents of consumer price consciousness in a turbulent economy”, International Journal of Consumer Studies, Vol. 41 No. 4, pp. 404-414.

Hampson, D.P., Grimes, A. Banister, E. and McGoldrick, P.J. (2018) "A typology of consumers based on money attitudes after major recession", Journal of Business Research, Vol. 91 No. pp. $159-168$

Herrman, H., Stewart, D.E., Diaz-Granados, N., Berger, E.L., Jackson, B. and Yuen, T. (2011), "What is resilience?" Canadian Journal of Psychiatry, Vol 56 No. 5, pp. 258-65.

Horváth, C., and Birgelen, M.V. (2015), "The role of brands in the behavior and purchase decisions of compulsive versus noncompulsive buyers", European Journal of Marketing, Vol. 49 No. 1/2, pp. 2-21.

Kamakura, W. A., \& Yuxing Du, R. (2011), "How economic contractions and expansions affect expenditure patterns". Journal of Consumer Research, Vol. 39 No. 2, pp. 229-247. 
Karanika, K. and Hogg, M.K. (2016), "Consumption through the ambivalent prism of intergenerational support", European Journal of Marketing, Vol. 50 No. 3/4, pp.575-601.

Kaytaz, M., \& Gul, M. C. (2014), "Consumer response to economic crisis and lessons for marketers: The Turkish experience”, Journal of Business Research, Vol. 67 No. 1, pp. 27012706.

Koos S, Vihalemm T, Keller M. (2017), "Coping with crises: Consumption and social resilience on markets", International Journal of Consumer Studies, Vol. 41 No. 4, pp. 363370.

Kogut, T., Eyal, T., \& Sharon, I. (2017), "Seeing into the future: Future time orientation as a moderator of temporal distance effects on educators' decisions", Journal of Behavioral Decision Making, Vol. 30, No. 4, pp. 889-898.

Krugman P. (2012), End This Disaster Now, New York, Norton.

Lamey, L. (2014), "Hard economic times: a dream for discounters", European Journal of Marketing, Vo. 48 No. 3/4, pp. 641-656.

Lazarus, R. S. (1993), "From psychological stress to the emotions, A history of changing outlooks", Annual Review of Psychology, Vol. 44 No. 1, pp. 1-21.

Longstaff, P.H. (2005), "Security, resilience, and communication in unpredictable environments such as terrorism, natural disasters, and complex technology" Program on Information Resources Policy, Centre for Information Policy Research, Harvard University, November, pp. i-103.

Luthans, F. (2002), "The need for and meaning of positive organizational behavior", Journal of Organizational Behavior; Vol. 23 No. 6, pp. 695-7-6.

McCracken, G. (1988), The Long Interview, Vol. 13, Sage, Thousand Oaks.

McCubbin, H. I., Joy, C. B., Cauble, A. E., Comeau, J. K., Patterson, J. M., \& Needle, R. H. (1980), "Family stress and coping: A decade review", Journal of Marriage and the Family, Vol. 42 No. 4, pp.855-871.

Mason, M. and Baker, M. (2014), "Beyond vulnerability: Building resilient consumers and communities", in NA - Advances in Consumer Research, 42, eds. June Cotte and Stacy Wood, Duluth, MN: Association for Consumer Research, pp. 7.

Mick, D.G. and Fournier, S. (1998), "Paradoxes of Technology: Consumer Cognizance, Emotions, and Coping Strategies", Journal of Consumer Research, Vol. 25, September, pp.123-143

Miles, M.B. and Huberman, A.M. (1994), Qualitative Data Analysis: An Expanded Sourcebook, Sage, Thousand Oaks. 
Moen, P. (1979), "Family impacts of the 1975 recession: Duration of unemployment." Journal of Marriage and the Family, Vol. 41 August, pp: 561-573.

Neocleous, M. (2012), "Don't be scared, be prepared: Trauma-anxiety-resilience", Alternatives, Vol. 37 No. 3, pp. 188-98.

Norris, F. H., S. P. Stevens, Pfefferbaum, B., Wyche, K.F. and Pfefferbaum, R. L. (2008), "Community resilience as a metaphor, theory, set of capacities, and strategy for disaster readiness" American Journal of Community Psychology, Vol. 41 No. 1-2, pp. 127-150.

O’Loughlin, D, Szmigin, I., McEachern, M., Karantinou, K., Barbosa, B. and FernandezMoya. M. E. (2017a) “"Man Thou Art Dust': Rites of Passage in Austere Times”, Sociology, Vol. 51, No. 5, pp. 1050- 1066.

O’Loughlin, D, Szmigin, I., McEachern, M., Karantinou, K., Barbosa, B. and FernandezMoya. M. E, Lamprinakos, G. (2017b) "European Consumers and their Persistent Resilience in the Face of Austerity", Advances in Consumer Research, Volume 45, eds. Ayelet Gneezy, Vladas Griskevicius, and Patti Williams, Duluth, MN: Association for Consumer Research, pp. 785-786.

Oswick, C., Fleming, P. and Hanlon, G. (2011). "From borrowing to blending: rethinking the processes of organizational theory building". Academy of Management Review, Vol. 36 No. 2, pp 318-337

Ozanne, L. and Ozanne, J.L. (2016), "How alternative consumer markets can build community resiliency”, European Journal of Marketing, Vol. 50 No. 3/4, pp. 330-357.

Peston R (2012), How Do We Fix This Mess? Hodder and Stouton, London.

Porral, C., Stanton, J.L, Levy-Mangin, J-P (2016), "Is the Economic Crisis Changing Marketing Strategies? Evidence from the Food Industry", Journal of Global Marketing, Vol. 29 No. 1, pp. 29-39.

Raab, C.D., Jones, R. and Szekely, I. (2015), "Surveillance and resilience in theory and practice", Media and Communication, Vol.3 No. 2, pp. 21-41.

Robertson, I. and Cooper, G. (2013), "Resilience" Stress and Health, Vol. 29 August, pp.175-176.

Rollins, M., Nickell, D., \& Ennis, J. (2013), "The impact of economic downturns on marketing", Journal of Business Research, Vol. 28 No. 5, pp. 455-461.

Rutter, M. (2012), "Resilience as a dynamic concept", Development and Psychopathology Vol. 24 No. 2, pp. 335-344.

Shama, A. (1981) "Coping with stagflation: voluntary simplicity". The Journal of Marketing, Vol. 45 Summer, pp. 120-134.

Spiggle, S. (1994), "Analysis and interpretation of qualitative data in consumer research", Journal of Consumer Research, Vol. 21 No. 3, pp. 491-503. 
Strutton, D., \& Lewin, J. (2012), 'Investigating consumers' responses to the Great Recession”. Journal of Consumer Marketing, Vol. 29 No. 5, pp. 378-388.

Stuckler, D, Reeves, A., Loopstra, R., Karanikolos, M., McKee, M. (2017), “Austerity and health: The impact in the UK and Europe", European Journal of Public Health, Vol. 27 No. 4, pp. 18-21.

Veer, E., Ozanne, L. K., \& Hall, C. M. (2016), "Sharing cathartic stories online: The internet as a means of expression following a crisis event", Journal of Consumer Behaviour, Vol. 15 No. 4, pp. 314-324.

Warde A. (2005), "Consumption and Theories of Practice", Journal of Consumer Culture, Vol. 5 No. 2, pp. 131-153.

Weick, K.E. and Sutcliffe, K.M. (2007), Managing the Unexpected: Resilient Performance in an Age of Uncertainty, $2^{\text {nd }}$ Edition, Jossey-Bass, San Francisco.

Weinberger, M. F., Zavisca, J. R., \& Silva, J. M. (2017), "Consuming for an imagined future: Middle-class consumer lifestyle and exploratory experiences in the transition to adulthood", Journal of Consumer Research, Vol. 44 No. 2, pp. 332-360.

Youssef, C. and Luthans, F. (2007), "Positive organisational behavior in the workplace: The impact of hope, optimism and resilience", Journal of Management, Vol. 33 No 5, pp. 774800 .

Zestanakis, P. (2018), "Online memories of 1980s-2000s lifestyle and consumption politics in Greece during the current economic crisis (2009-2015)", Journal of Consumer Culture, Online First, pp. 1-22.

Zurawicki, L., \& Braidot, N. (2005), "Consumers during crisis: responses from the middle class in Argentina”, Journal of Business Research, Vol. 58 No, 8, pp. 1100-1109. 
Table 1 Theories of Resilience

\begin{tabular}{|c|c|c|c|c|}
\hline & Consumer Coping & $\begin{array}{l}\text { Resilience } \\
\text { (Traditional Perspective) }\end{array}$ & $\begin{array}{l}\text { Persistent Resilience } \\
\text { (Urban Studies) }\end{array}$ & $\begin{array}{l}\text { Persistent Resilience } \\
\text { (Marketing \& Consumption) }\end{array}$ \\
\hline $\begin{array}{l}\text { Key } \\
\text { Authors }\end{array}$ & $\begin{array}{l}\text { McCubbin 1980; } \\
\text { Mick \& Fournier, 1998; } \\
\text { Hampson \& McGoldrick 2013; } \\
\text { Cappellini } \text { et al. 2014; } \\
\text { Bartfield \& Collins, } 2017\end{array}$ & $\begin{array}{l}\text { Block \& Kremen 1996; } \\
\text { Robertson \& Cooper 2013; } \\
\text { Mason \& Baker 2014; } \\
\text { Koos et al., } 2017\end{array}$ & $\begin{array}{l}\text { Golubchikov, 2011; } \\
\text { DeVerteuil \& Golubchikov, 2016; } \\
\text { Andres \& Round } 2015\end{array}$ & \\
\hline $\begin{array}{l}\text { Key } \\
\text { Components } \\
\text { Attributes }\end{array}$ & $\begin{array}{l}\text { Behavioural, Psychological, } \\
\text { Collective } \\
\text { Adaptation } \\
\text { One-off to Enduring } \\
\text { Short to Longer term } \\
\text { Reactive }\end{array}$ & $\begin{array}{l}\text { Behavioural, Psychological, } \\
\text { Social, Community } \\
\text { Ultimate Return to Previous } \\
\text { State } \\
\text { One-off } \\
\text { Short term } \\
\text { Reactive }\end{array}$ & $\begin{array}{l}\text { Relational, Spatial, } \\
\text { Political } \\
\text { Continuous Renegotiation } \\
\text { /Flexible Adaptation } \\
\text { Enduring } \\
\text { Long-term } \\
\text { Reactive \& Proactive }\end{array}$ & $\begin{array}{l}\text { Day-to day Coping } \\
\text { Relating } \\
\text { Pragmatism } \\
\text { Adjustment to } \\
\text { Transformation } \\
\text { Temporal Response to } \\
\text { Persistent Stressors } \\
\text { Long-term } \\
\text { Reactive \& Proactive } \\
\text { Resistance, Reduction \& } \\
\text { Alternative Consumption }\end{array}$ \\
\hline
\end{tabular}


Table 2 Profile of Participants

\begin{tabular}{|c|c|c|c|c|c|c|c|}
\hline No. & Name & Nationality & $\begin{array}{l}\text { Gende } \\
\mathbf{r}\end{array}$ & Age & Profession/Employment & Relationship & Children \\
\hline 1 & Robert & Irish & Male & 38 & Senior Court Clerk & Married & 2 Young Children \\
\hline 2 & Ruth & Irish & Female & 42 & Community College Teacher & $\begin{array}{l}\text { Single } \\
\text { Mother }\end{array}$ & 1 Young Child \\
\hline 3 & Brid & Irish & Female & 56 & Training Consultant & Married & 2 Adult Children \\
\hline 4 & Susan & Irish & Female & 46 & $\begin{array}{l}\text { Founder of Charity Receiving } \\
\text { Unemployment Benefit }\end{array}$ & Married & 2 Teenage Children 1 Adult Child \\
\hline 5 & Sophie & Irish & Female & 29 & $\begin{array}{l}\text { Fulltime Volunteer Receiving } \\
\text { Disability Benefit }\end{array}$ & Single & No Children \\
\hline 6 & Alma & Irish & Female & 54 & $\begin{array}{l}\text { Part-time Volunteer Receiving } \\
\text { Unemployment Benefit }\end{array}$ & Married & 2 Adult Children \\
\hline 7 & David & Irish & Male & 60 & $\begin{array}{l}\text { Fulltime Student Receiving Back to } \\
\text { Education Benefit }\end{array}$ & Separated & 2 Adult Children \\
\hline 8 & Emma & UK & Female & 22 & $\begin{array}{l}\text { Unemployed Office Administrator, } \\
\text { Part-time Kitchen Staff }\end{array}$ & $\begin{array}{l}\text { In a } \\
\text { Relationship }\end{array}$ & No Children \\
\hline 9 & Claire & UK & Female & 53 & Retired University Professor & Single & No Children \\
\hline 10 & Martina & UK & Female & 44 & University Librarian & Married & 1 Young Child \\
\hline 11 & Lisa & UK & Female & 40 & Self-Employed Transcriber & Married & No Children \\
\hline 12 & Linda & UK & Female & 55 & Carer & Married & 1 Adult Child \\
\hline 13 & Derek & UK & Male & 64 & Self -Employed Carpenter & Married & 2 Adult Children \\
\hline 14 & Louise & UK & Female & 45 & Teacher & Divorced & 2 Teenage Children \\
\hline 15 & Maria & Portuguese & Female & 49 & Stay at home Mum & Married & 1 Teenage Child 1 Adult Child \\
\hline 16 & Helena & Portuguese & Female & 39 & Architect & Married & 4 Young Children \\
\hline 17 & Manuel & Portuguese & Male & 53 & Unemployed Construction Worker & Married & 1 Young Child 1 Teenage Child \\
\hline 18 & Rita & Portuguese & Female & 33 & Petrol Station Shop Assistant & Married & No Children \\
\hline 19 & Amelia & Portuguese & Female & 21 & Unemployed Shop Assistant & Single & No Children \\
\hline 20 & Filipe & Portuguese & Male & 65 & Doctor & Married & 3 Adult Children \\
\hline 21 & Luisme & Spanish & Male & 27 & Part-time Student/Unemployed & $\begin{array}{l}\text { In a } \\
\text { Relationship }\end{array}$ & No Children \\
\hline 22 & Rosa & Spanish & Female & 60 & Gardner & Married & 1 Adult Child \\
\hline 23 & Bernado & Spanish & Male & 46 & Orthopaedic Surgeon & Married & 1 Young Child \\
\hline 24 & Elena & Spanish & Female & 30 & Unemployed University Lecturer & Single & No Children \\
\hline 25 & Pepe & Spanish & Male & 34 & Entrepreneur & $\begin{array}{l}\text { In a } \\
\text { Relationship }\end{array}$ & No Children \\
\hline 26 & Ana & Spanish & Female & 58 & Unemployed Dressmaker & Married & 2 Adult Children \\
\hline 27 & Antonio & Spanish & Male & 38 & Unemployed Commercial Director & Single & No Children \\
\hline 28 & Yiannis & Greek & Male & 38 & Fulltime University Academic & Married & 2 Young Children \\
\hline 29 & Christina & Greek & Female & 53 & Artist Employed Part-time & Married & 2 Teenage Children \\
\hline 30 & Elisa & Greek & Female & 46 & Part-time Teacher & Married & 2 Young Children \\
\hline 31 & Irene & Greek & Female & 40 & Fulltime HRM position & Single & No Children \\
\hline 32 & Nikolaos & Greek & Male & 41 & $\begin{array}{l}\text { Unemployed - Setting up Financial } \\
\text { Advisory Business }\end{array}$ & Married & 2Young Children \\
\hline 33 & Luisa & Italian & Female & 47 & Unemployed Freelance Worker & Divorced & 1 Adult Child \\
\hline 34 & Rosella & Italian & Female & 42 & Gym Instructor & Single & No Children \\
\hline 35 & Iron & Italian & Male & 18 & Student & Single & No Children \\
\hline 36 & Giancarlo & Italian & Male & 47 & Sales Manager & Divorced & 2 Young Children \\
\hline 37 & Gino & Italian & Male & 47 & Self-Employed & Married & 2 Adult Children \\
\hline 38 & Mirella & Italian & Female & 51 & Sales Representative & Married & 1 Teenage Child \\
\hline
\end{tabular}


Figure 1 Thematic Map - Visualising Persistent Resilience

Persistent Stressors

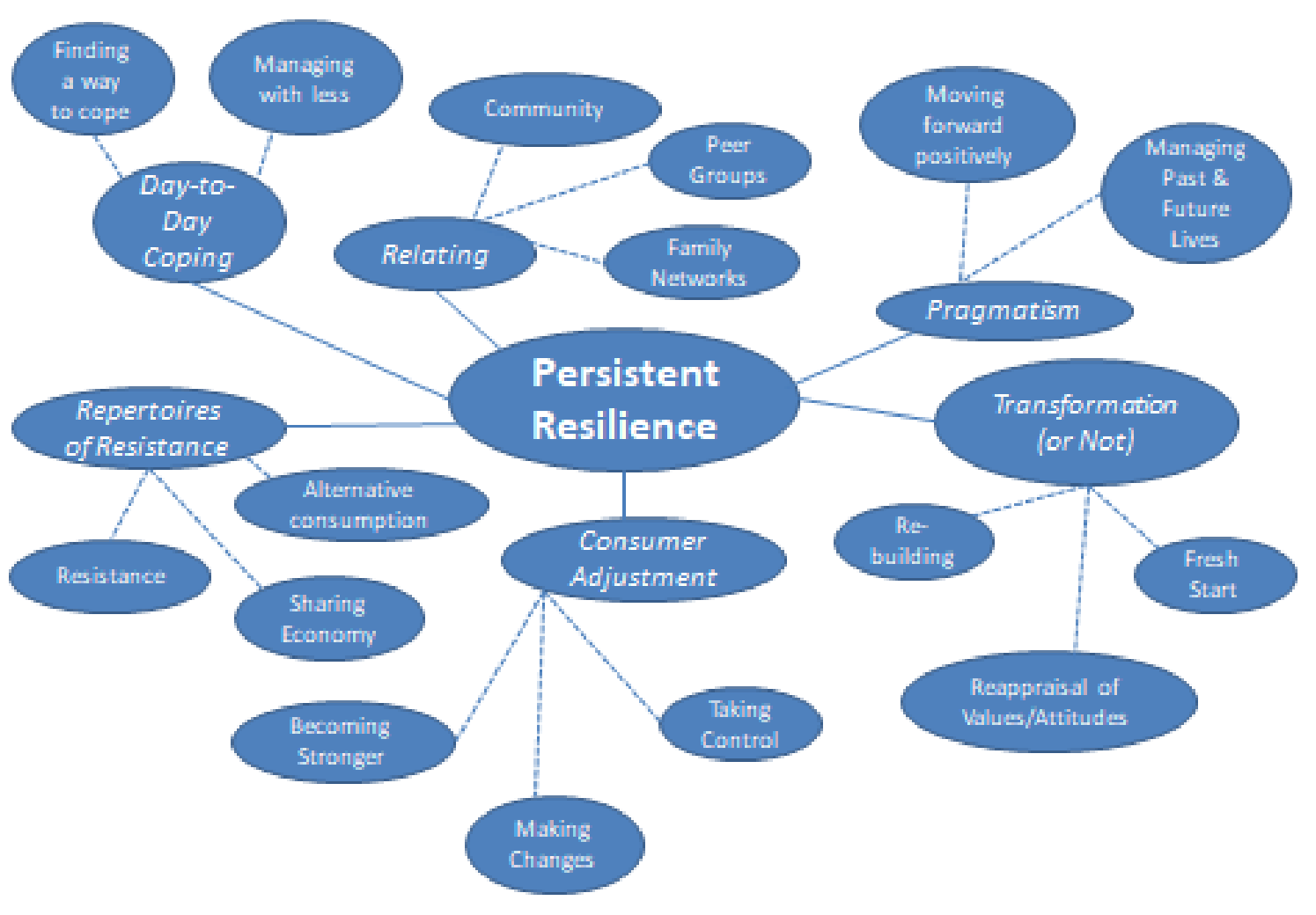

Temporal Orientation 
